\title{
THE EFFECT OF THE TYPE OF ELEMENTS USED TO STIFFEN THIN-WALLED SKINS OF LOAD-BEARING AIRCRAFT STRUCTURES ON THEIR OPERATING PROPERTIES. EXPERIMENTALTESTS AND NUMERICAL ANALYSIS
}

\section{WPŁYW RODZAJÓW USZTYWNIEŃ POKRYĆ CIENKOŚCIENNYCH STRUKTUR NOŚNYCH STATKÓW POWIETRZNYCH NA ICH WŁAŚCIWOŚCI EKSPLOATACYJNE. BADANIA EKSPERYMENTALNE I ANALIZA NUMERYCZNA*}

\begin{abstract}
The paper presents results of a study on thin-walled structures modelling representative fragments of aircraft fuselages subjected to bending and torsion. The type of the considered load and deformation corresponds to the state of such structures under in-flight conditions. The subject of the study were structures made of composite materials. Adopted assumptions include admissibility of post-buckling deformation in the operating load regime. Results of experimental studies are presented together with nonlinear numerical analyses carried out with the use of the finite elements method applied to a number of variant structures provided with various types of skin stiffening elements. Operating properties of the examined structures have been compared on the grounds of adopted criteria.
\end{abstract}

Keywords: thin-walled structures, loss of stability, aircraft load-bearing structures, finite elements method, nonlinear numerical analyses, operating stability.

\begin{abstract}
Praca prezentuje wyniki badań ustrojów cienkościennych, stanowiących modele reprezentatywnych fragmentów struktur lotniczych, poddawanych zginaniu oraz skręcaniu. Rodzaj obciażenia oraz deformacji odpowiada stanowi struktury w warunkach eksploatacji. Przedmiotem rozważań były ustroje wykonane z kompozytów. Przyjęto założenie o dopuszczalności deformacji zakrytycznych dla obciążen eksploatacyjnych. Przedstawiono wyniki badań eksperymentalnych i nieliniowych analiz numerycznych w ujęciu metody elementów skończonych szeregu wariantów ustrojów, zawierających różne rodzaje usztywnień pokryć. Dokonano porównania właściwości eksploatacyjnych badanych ustrojów, w oparciu o przyjęte kryteria.
\end{abstract}

Stowa kluczowe: ustroje cienkościenne, utrata stateczności, lotnicze struktury nośne, metoda elementów skończonych, nieliniowe analizy numeryczne, trwatość eksploatacyjna.

\section{Introduction}

Scientific research projects concerning the issue of the loss of stability of sub-structures constituting elements of larger load-bearing structures used in the engineering practice are usually focused on problems relating to determination of critical load values. Post-buckling states of structures are the subject of analyses much more seldom. It follows from the fact that in most of the areas of engineering, the instant at which a structure loses its stability is considered to be the moment of its destruction $[1,10,13]$.

In the aircraft construction technology, in view of very specific nature of structures being the subject of considerations, equally specific standards have been established affecting both design processes and principles of operation. One of the rules, applicable to metal structures still most popular in the aircraft industry, provides admissibility of post-buckling deformations in selected types of structures under the in-flight load conditions $[2,11,12]$.

It should be underlined that, similarly as in other disciplines of engineering, an iron rule is commonly accepted according to which a bar structure subjected to buckling is considered destroyed. Reliability of a structure depends therefore on adequately rigorous selection of geometrical parameters for all structure components which are represented by bar frameworks in the model design process. These include e.g. stringers, elements of frames and lattices, spar flanges, etc.

A completely different rule applies to sheet-shaped structures constituting components of semi-monocoque fuselages, however also in this case a number of limitations exist. In general, in view of the necessity to minimise the mass of the object, the loss of stability of the skin in operating conditions is assumed to be admissible provided the phenomenon has an elastic and local nature, i.e. occurs locally within the area of skin segments limited by components of the skeleton. Exceptions include skins of e.g. wing torsion boxes and other structural elements responsible for maintaining appropriate torsional rigidity, as well as these skin fragments large deformations of which are undesired in view of the necessity to maintain specific aerodynamic properties of the object $[8,14,18,19]$.

Although structures made of lightweight metals are still the basic components in most of currently operated load-bearing aircraft fuselages, recent years saw a distinct trend towards increased application of composites of various types. Those most commonly used in the

(*) Tekst artykułu w polskiej wersji językowej dostępny w elektronicznym wydaniu kwartalnika na stronie www.ein.org.pl 
aircraft industry include layered composites based on glass, carbon, and aramid fibre fabrics and polymer resins.

In view of insufficient knowledge concerning the whole of changes occurring in mechanical properties of composites during prolonged operation, load-bearing components made with the use of this very technology were for many years designed and fabricated as monocoque structures with interlayers preventing stressed skins from the loss of stability.

Nowadays, striving to meet still more and more rigorous operating and economic criteria, aircraft structure designers have adopted the doctrine admitting a local loss of stability for some fragments of composite skins, similar to his accepted earlier for metal fuselage components $[6,7,16]$.

This allowed to make use of semi-monocoque structures characterised with more favourable mechanical properties than those demonstrated by monocoque design solutions as far as the mass criterion is considered.

Before admitting structures of that type to operation it is necessary to carry out comprehensive studies on the effect of prolonged cyclic loads applied to composite structures on their condition and reliability.

Admitting the loss of stability in composite skins induces occurrence of design problems similar to those encountered in structures with metal sheet skins. One of such issues is related to the necessity to limit the phenomenon as effectively as possible, with the structure mass increase reduced to a minimum. It seems to be appropriate to achieve the target by employing integral stiffening elements. An indisputable merit of composite materials is the possibility of giving them arbitrary shapes. As a result, geometries of integral elements stiffening composite skins are usually different than those used for metal skins, and feasibility of realising individual design concepts is subject to different technological limitations.

Procedures applicable to design work on structures of that type processes employ universally numerical tools, including various software packages based on the finite elements method. To determine displacement distribution patterns in cases of existence of post-buckling deformations, it is necessary to realise nonlinear numerical analyses with geometrical nonlinearities taken into account. In view of the limited accuracy of numerical methods, results obtained by means of these tools are very frequently biased with significant errors $[5,9]$. The only way to eliminate them consists in elaborating the numerical models by means of relevant experimental verification. In most cases, such verification can be based on simplified test carried out on models in the course of which measurements of displacements in a set of predetermined reference points are taken. Once conformity of deformation patterns and magnitudes calculated numerically and observed in the experiment is achieved, it is possible to obtain reliable reduced stress distributions within the framework of the selected mechanical strength hypothesis. The base on which such reliability is assumed is the rule of uniqueness of solutions according to which one and only one distribution of the reduced stress corresponds to each deformation state [3].

\section{Purpose and scope of the study}

The purpose of the study presented in this paper was to carry out a comparative analysis of several design solutions concerning a fragment of aeroplane wing with composite skin subjected to post-critical deformations under permissible operating load conditions. The subject of the research were structures with identical dimensions (Fig. 1) differing in the skeleton structure designs. In each of the cases, the front portion of the skin corresponding to the torsion box was given a larger thickness thus protecting it against the loss of stability. In the course of analyses, special attention was attached to areas between the spar and the trailing edge.
In all variants, the same skin making technology and thickness were used. As a result of the experiment, deformation distribution patterns have been obtained and representative equilibrium paths determined. The obtained results were used as a base for elaboration and verification of numerical models subjected to nonlinear analyses with the use of software based on the finite elements method.

The overall outcome of the study can be considered confirmation of appropriateness of the numerical models which can be used as a base for determining usefulness of another modifications of the analysed design solutions.

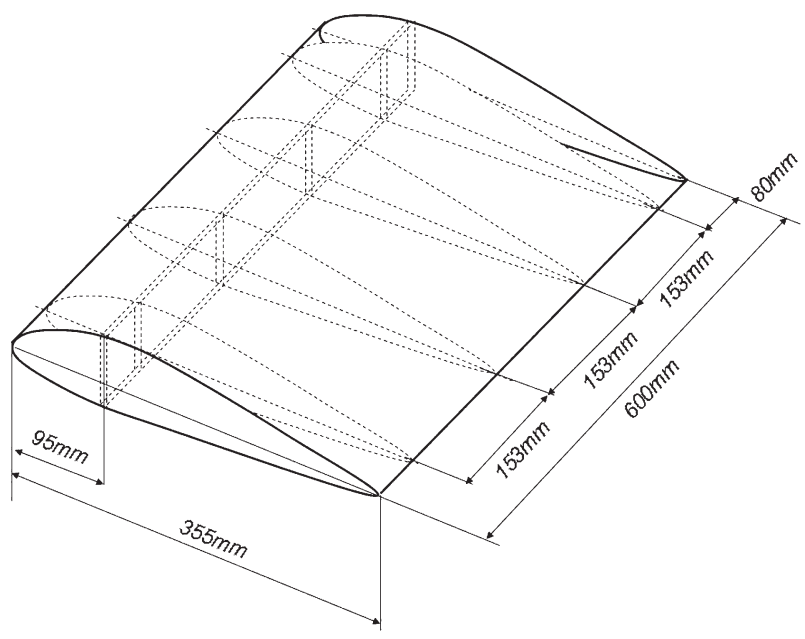

Fig. 1. Schematic views and dimensions of the examined structures

\section{The experiment}

The skeleton structure of the model used in the experiment was made of plywood and wooden slats with known mechanical parameters. The skin was made of an epoxy resin glass-fibre reinforced composite (GFRP).

As the composite reinforcement, Interglass glass fibre fabrics were used with weight ratios of $50 \mathrm{~g} / \mathrm{m}^{2}$ and $163 \mathrm{~g} / \mathrm{m}^{2}$. The matrix was a saturating mix based on epoxy resin MGS L285/H286 with known mechanical properties which corresponded to those measured for the composite material, i.e. $E_{11}=22000 \mathrm{MPa}, E_{22}=22000 \mathrm{MPa}$, $v_{12}=0.11, G_{12}=4600$. In the torsion box area, skin of the model was made a structure comprising four layers of the symmetric fabric with reinforcement ratio of 50/50. The main directions of the composite ortotrophy were oriented at the angle of 45 degrees with respect to the direction of spar flanges.

The remaining portion of the structure contained three layers of fabric (Fig. 2). Such differentiation in the number of layers was aimed at

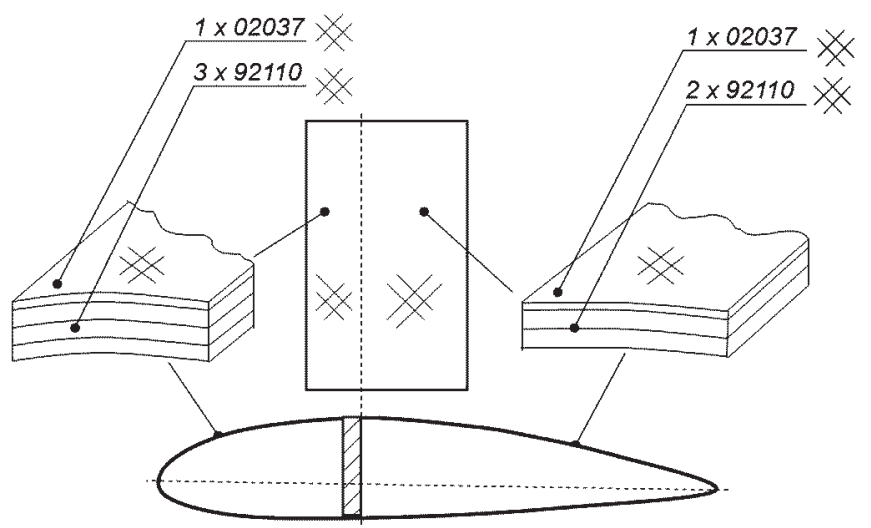

Fig. 2. Schematic representation of the laminated structure 


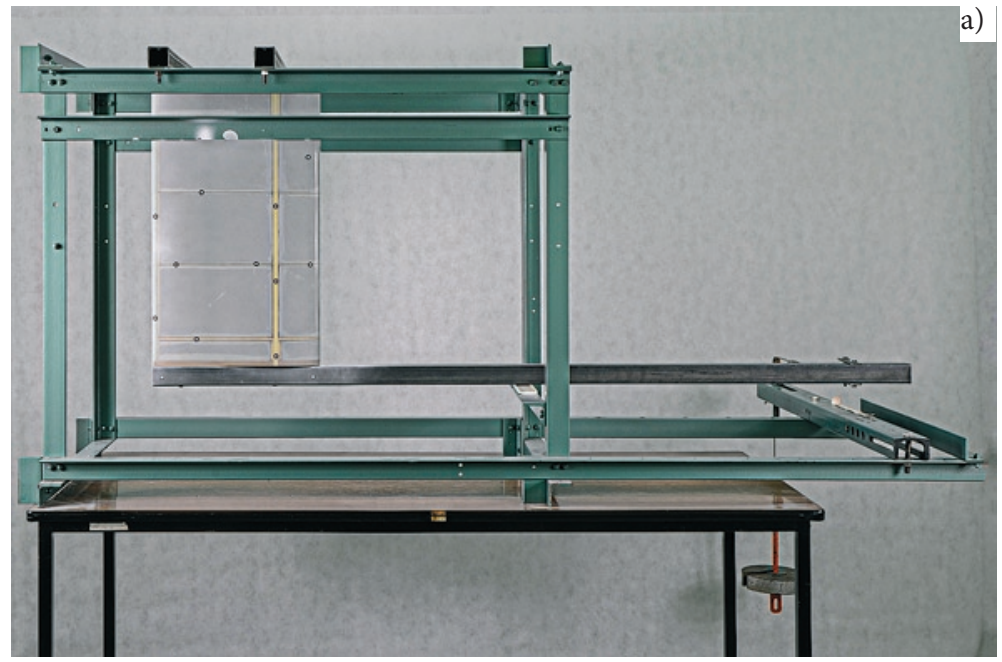

protecting the torsion box surface against the loss of stability and creating conditions favourable to occurrence of post-critical deformations in the skin area between the spar and the trailing edge.

The experiments were carried out with the use of a specifically designed set-up (Fig. 3(a)). The examined models were

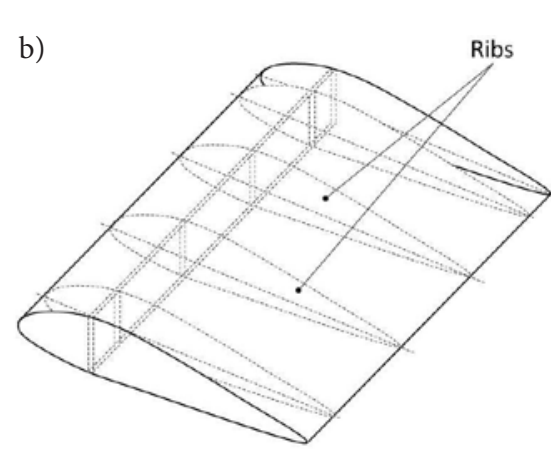
subjected to torsion and bending which corresponded to the actual nature of loads applied to an aeroplane wing in the inflight conditions (Fig. 3(b)). The load was applied gravitationally.

Three variants

Fig. 3. (a) The experimental set-up; (b) schematic diagram of structure mounting and load application

of the model were examined (Fig. 4).
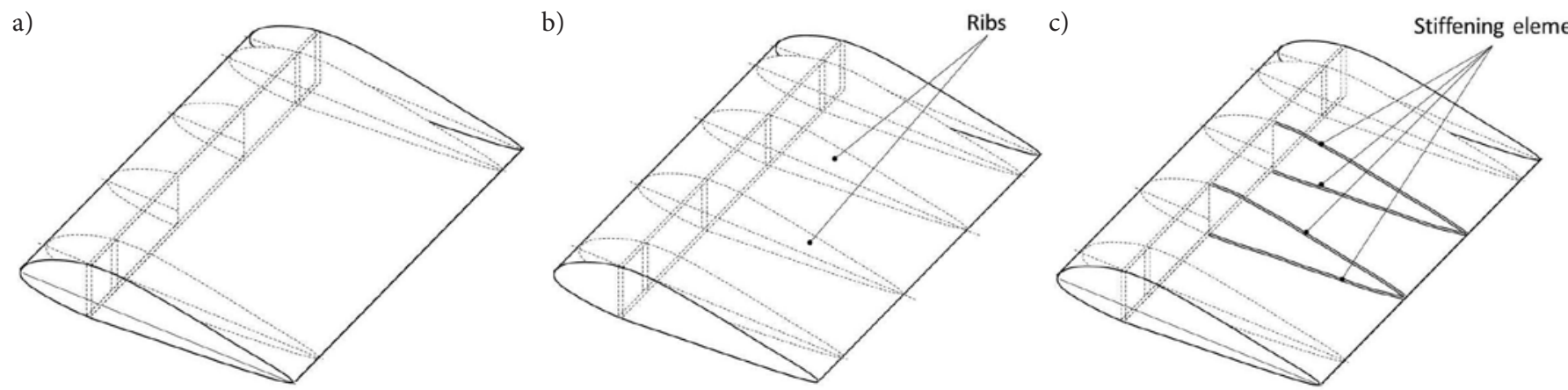

Fig. 4. Schematic sketches of examined model versions: (a) without stiffening elements; (b) with ribs; (c) with stiffening elements

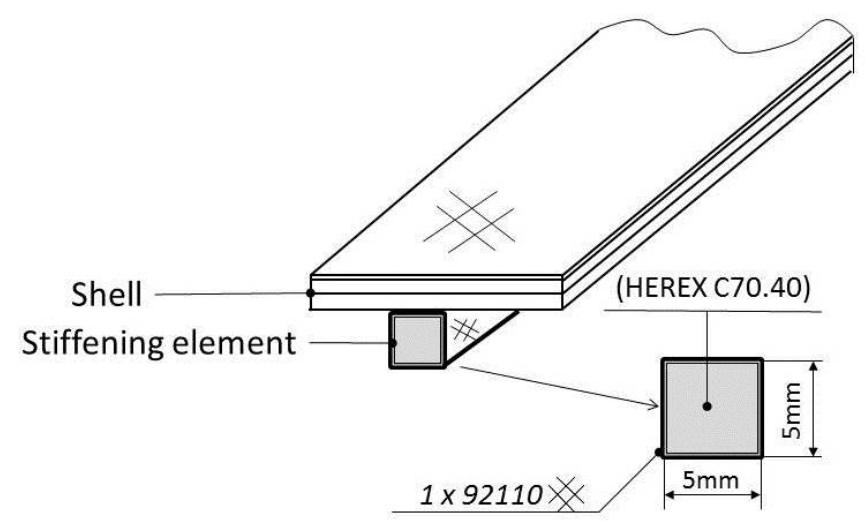

Fig. 5. A schematic view of skin stiffening elements

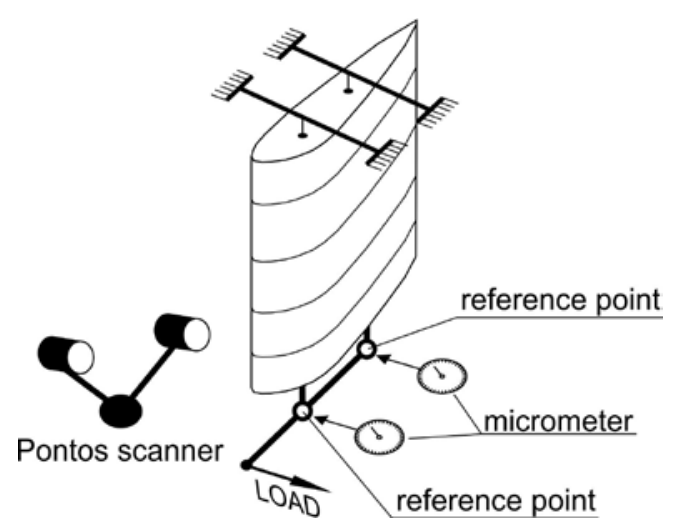

Fig. 6. Reference point displacement measuring technique

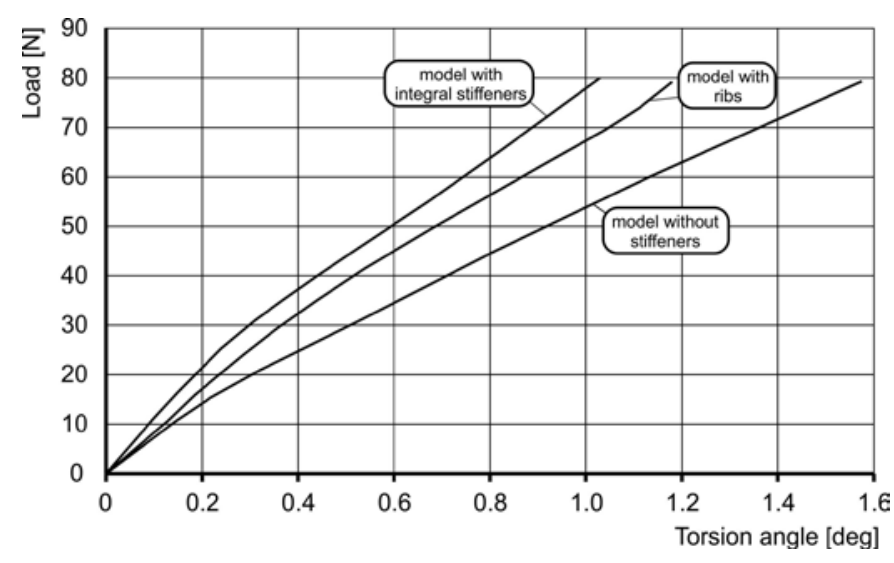

Fig. 7. Comparison of representative equilibrium paths

In the first variant, the tested skin fragment had no stiffening elements. Complete skeleton comprising middle ribs was applied in the second variant. In the third version of the model was provided with stiffening elements in the form of perimeters of a figures filled in with polymer foam (Fig. 5). Structure of that type would not be categorised as the integral stiffening element in the commonly adopted meaning of the term, however it serves the same function as an element in the form of perimeter of figure created by proper shaping of outer layer of the skin. Additionally, such solution is much easier to fabricate. For this reason, in the following this type of stiffening element will be referred to as the integral one.

In the course of the experiments, skin displacement measurements were taken in selected reference points for successive stationary deformation states of the structure. To this end, a system of micrometer gauges and PONTOS optical scanner by GOM Optical Measuring 
a)
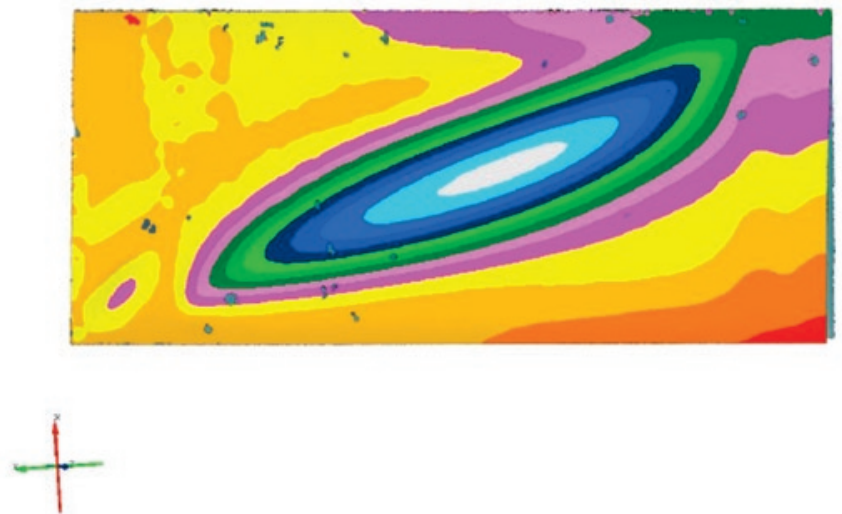

Fig. 8. Distribution of resultant displacement (in $\mathrm{mm}$ ) - the model without stiffening elements: (a) upper skin; (b) lower skin (ribs mounted on the right)

a)

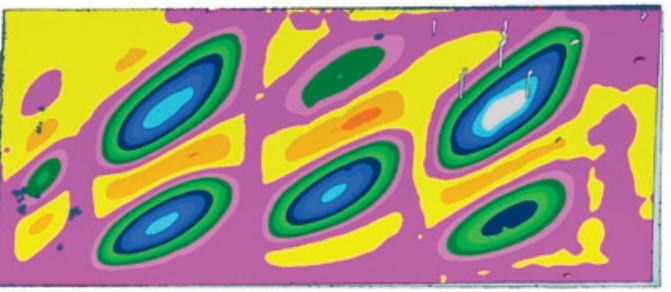

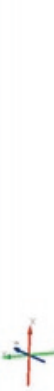
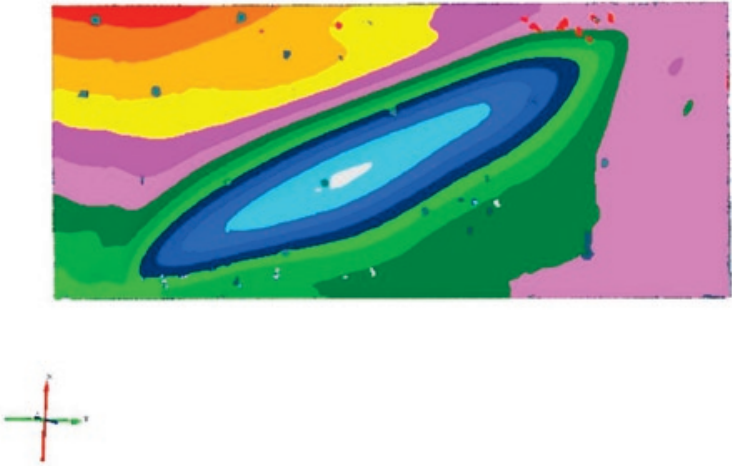

b)

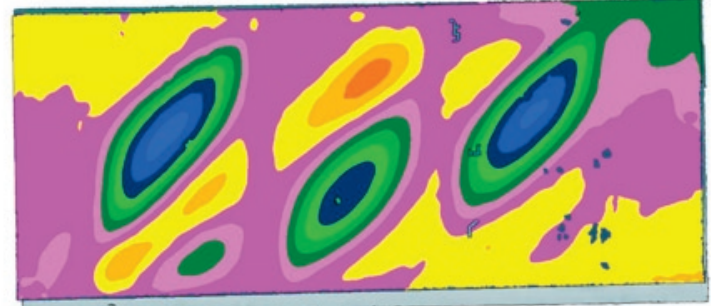

Fig. 9. Distribution of resultant displacement (in mm) - the model with ribs: (a) upper skin; (b) lower skin (ribs mounted on the right)

a)

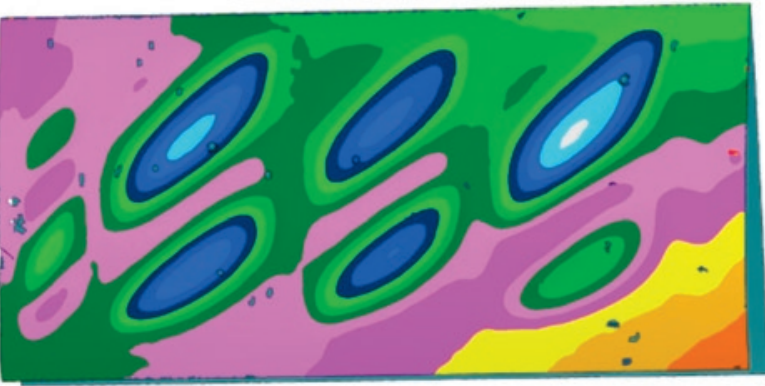

b)

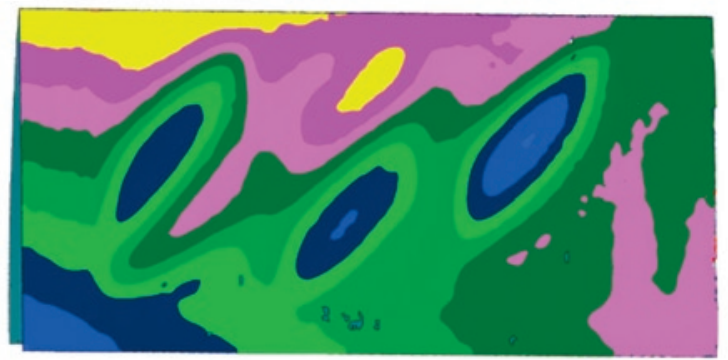

Fig. 10. Distribution of resultant displacement (in $\mathrm{mm}$ ) — the model with stiffening elements: (a) upper skin; (b) lower skin (ribs mounted on the right)

was used (Fig. 6). As a result, representative equilibrium paths have been obtained, representing the relationship between the total angle of torsion of the structure and the load value (Fig. 7).

Further, the examined area of the deformed model was scanned with the use of ATOS scanner for the target load value. As a result, images of the deformation field were obtained (Figs. 8-10) on the grounds of which results of numerical calculations were verified.

\section{Numerical analyses}

A necessary complement to the experimental phase allowing to obtain information about stress distribution patterns in the examined skins consists in development of appropriate and effective calculation models implemented by means of the finite elements method.

Numerical modelling of the examined structures was realised with the use of commercial software MSC PATRAN/MARC effectiveness of which proved to be effective in case of analyses concerning postbuckling deformations of skins made of isotropic materials $[11,12]$.
As far as composite materials are concerned, the decisive model development phase consists in application of an algorithm the purpose of which is to determine properties of the laminate based on sets of constants characterising individual layers. The algorithm constitutes and integral subroutine of the preprocessor and any intervention of the user in its structure is impossible.

A distinctive feature of composite structures, making development of their numerical representation exceptionally difficult, is their non-homogeneity resulting not only from conditions in which individual layers are laminated but also from assembling operations, i.e. presence of local excesses of resin and diversified thickness of bonded joints. Such factors can induce local skin stiffness variations and have an effect on post-critical deformation patterns. Even small errors in selection of geometric parameters for the numerical model, introducing definite deviations from actual boundary conditions characterising a skin segment, generate significant errors in the course of nonlinear analyses. 
The fundamental relationship in any nonlinear problem, determining quantitatively the relationship between condition of a structure and the load, is the so-called equilibrium path of the system constituting, in general, a hypersurface in the hyperspace of states [4, 9]. The relationship can be written as the following matrix equation of residual forces:

$$
\mathbf{r}(\mathbf{u}, \mathbf{\Lambda})=\mathbf{0},
$$

where $\mathrm{u}$ is the state vector containing displacement components of nodes of the structure corresponding to its current geometrical configuration, $\Lambda$ is a matrix composed of control parameters corresponding to the actual load level, and $r$ is the residual vector of uncompensated force components related to the current system deformation state. The set of control parameters can be represented by a single parameter $\lambda$ being a function of the load. In such case, equation (1) takes the form:

$$
\mathbf{r}(\mathbf{u}, \lambda)=\mathbf{0}
$$

called the single-parameter equation of residual forces.

The prediction-correction methods of determining the consecutive points of the equilibrium path used in contemporary software routines provide also for a correction phase based on the requirement that the system satisfies an additional equation called the increment control equation or the constraints equation $[9,17]$ :

$$
\mathrm{c}\left(\Delta \mathbf{u}_{n}, \Delta \lambda_{n}\right)=0,
$$

where the increments:

$$
\Delta \mathbf{u}_{n}=\mathbf{u}_{n+1}-\mathbf{u}_{n} \text {, and } \Delta \lambda_{n}=\lambda_{n+1}-\lambda_{n}
$$

correspond to transition from state $n$ to state $n+1$.

In view of lack of possibility to represent equilibrium paths for systems with more than two degrees of freedom in a form of easily interpretable plots, for the purpose of comparison, the so-called representative equilibrium paths are used in practice that represent a functional relationship between a selected parameter characterising deformation of the system and a single control parameter related to the applied load. Reliability of results obtained from FEM-based nonlinear numerical analyses is usually accepted when a satisfactory coherence is found between two representative equilibrium paths, namely the actual one determined in the course of an experiment and this obtained numerically. It is also necessary to obtain convergence between the forms of deformations following from the calculations $[4,9,17]$ with results of relevant experiment. On the grounds of the above-mentioned rule of uniqueness of solutions, the obtained re-

a)
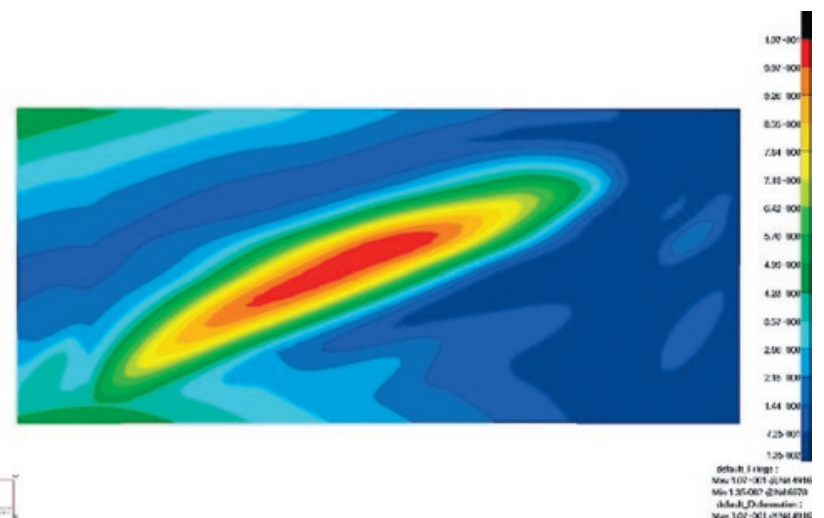

duced stress distributions in the deformed skin can be therefore also considered reliable [3].

As the nonlinear numerical analysis is an iterative process aimed at finding successive equilibrium states, its correctness is to a large degree determined by correct choice of the prognostic method, the correction strategy, and a number of control parameters. In the case described here, the Newton-Raphson method was used in combination with the Crisfield hyperspherical correction strategy [4, 15].

By contrast with linear analyses where the goal is to obtain as high number of finite elements as possible, selection of excessively dense mesh of elements for nonlinear analyses leads to faulty calculation results in many cases with the calculation time significantly extended. After a series of numerical tests aimed at selection of a proper topology for the model, it has been decided to use a model comprising 5000 four-node skin elements. The necessity to employ such elements resulted from the fact that other types available in the MSC MARC software library to which properties of laminated composites could be assigned do not offer the possibility to reproduce geometrically complex objects, in view of the type and number of the degrees of freedom.

Models of the materials were developed taking into account mechanical properties of composites fabricated with the use of components used in the experimental phase and characterised by means of material constants quoted in preceding chapter.

As a result of the performed nonlinear numerical analyses, representative equilibrium paths have been determined and compared to corresponding characteristic obtained from the experiment (Fig. 11).

Very small discrepancies between corresponding representative curves were found in all the cases subjected to analysis which confirmed that the numerical methods and parameters controlling nonlinear procedures were selected correctly.

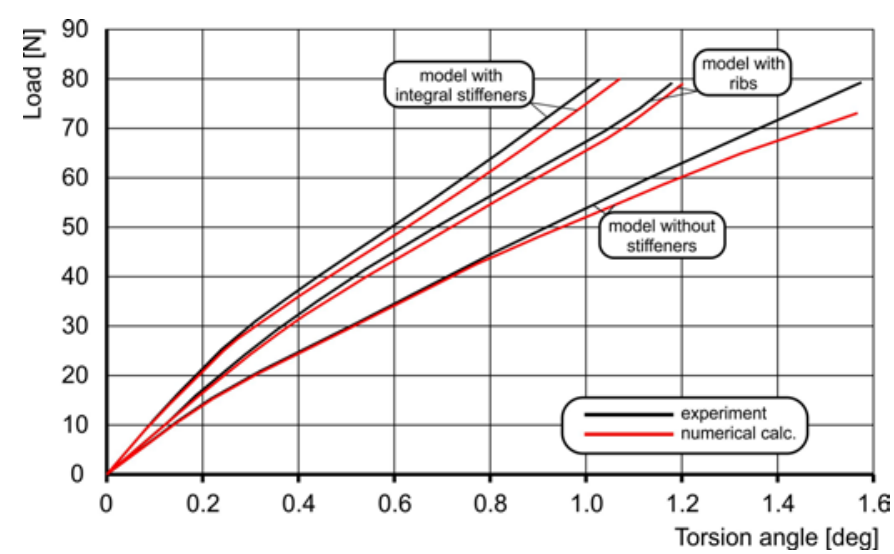

Fig. 11. Comparison of representative equilibrium paths

b)

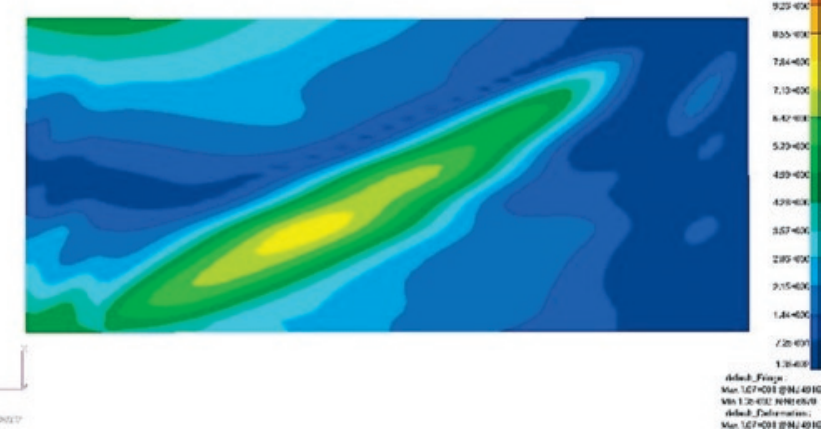

Fig. 12. Resultant displacement distribution patterns for the analysed skin fragments (in mm) — model without stiffening elements: (a) upper skin; (b) lower skin 
a)

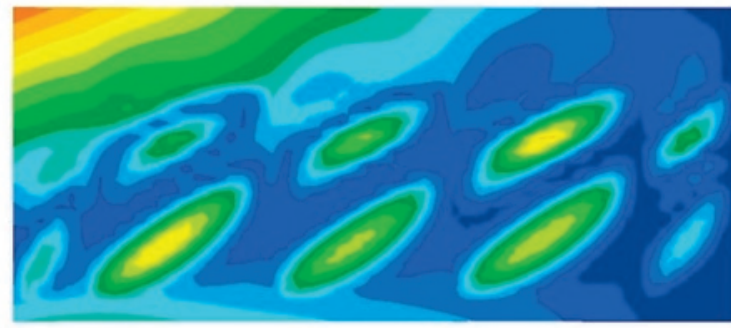

b)

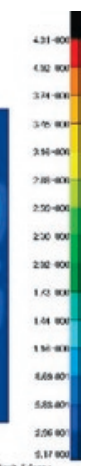

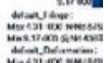

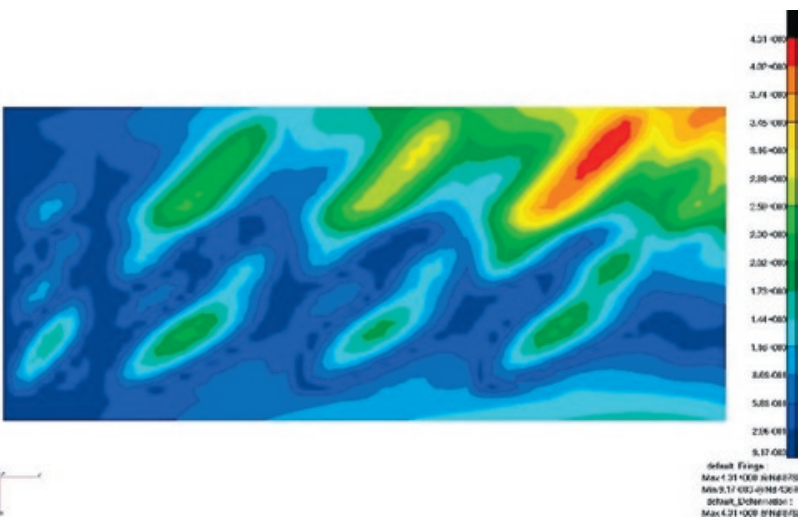

Fig. 13. Resultant displacement distribution patterns for the analysed skin fragments (in mm) - model with ribs: (a) upper skin; (b) lower skin

a)

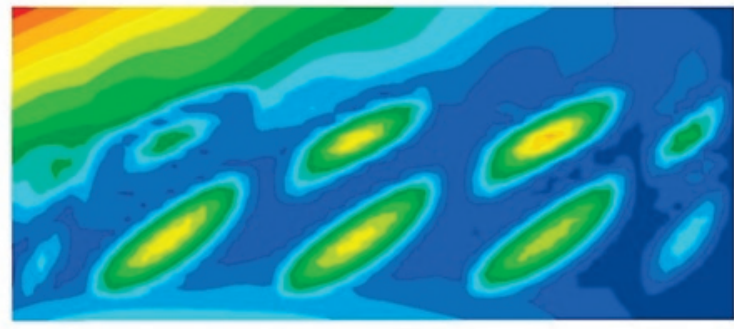

b)
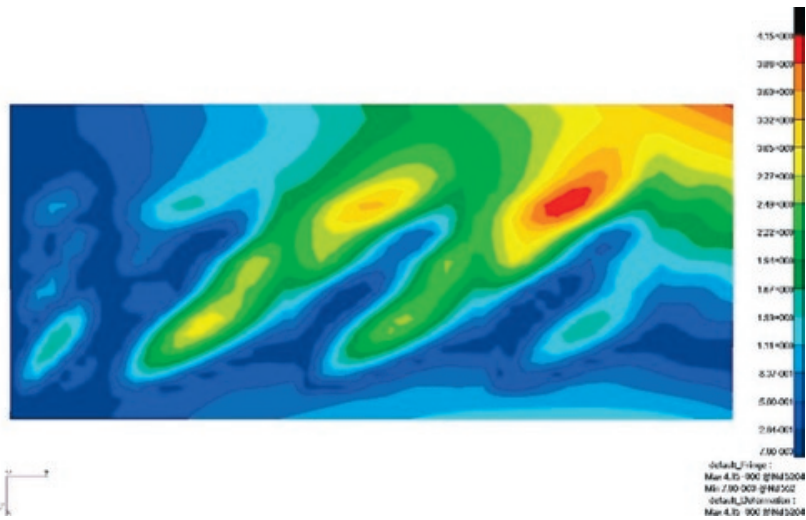

Fig. 14. Resultant displacement distribution patterns for the analysed skin fragments (in mm) - model with integral stiffening elements: (a) upper skin; (b) lower skin

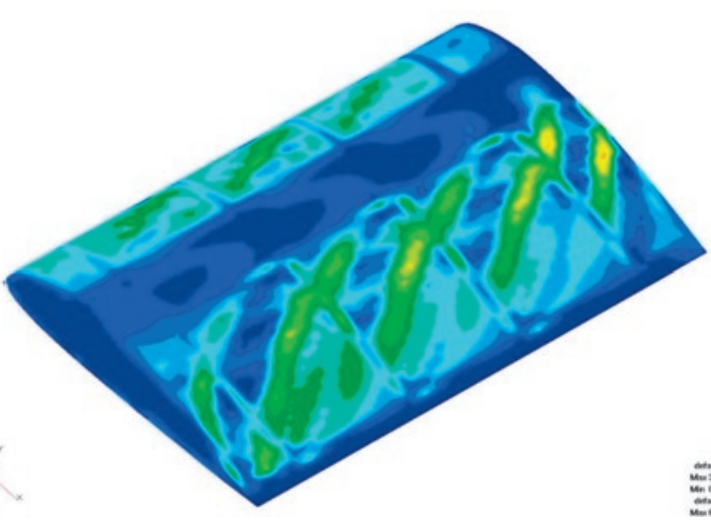

Fig. 15. Reduced stress distributions according to omax hypothesis

As a result of the analyses, distributions patterns of resultant displacements of the finite element mesh nodes constituting skin models haven been also obtained (Figs. 12-14).

Taking into account the satisfactory similarity between results of analyses on one hand and the experiment on the other observed in the scope of both representative equilibrium paths and resultant displacements, it can be stated that properties of composites attributed to finite elements by PATRAN software, determined by the program based on data for individual layers of the composite, may be considered correct and corresponding to actual characteristics. However, it should be emphasised that, in case of occurrence of any defects in the real structure that may arise in the process of lamination, it is necessary to introduce appropriate correction in the numerical model accounting for the effect of such flaws on local stiffness of the skin.

The courses of the representative equilibrium paths allow to claim that the wing skin stiffening elements constitute a necessary component of the structure. In the model lacking these features, loss of

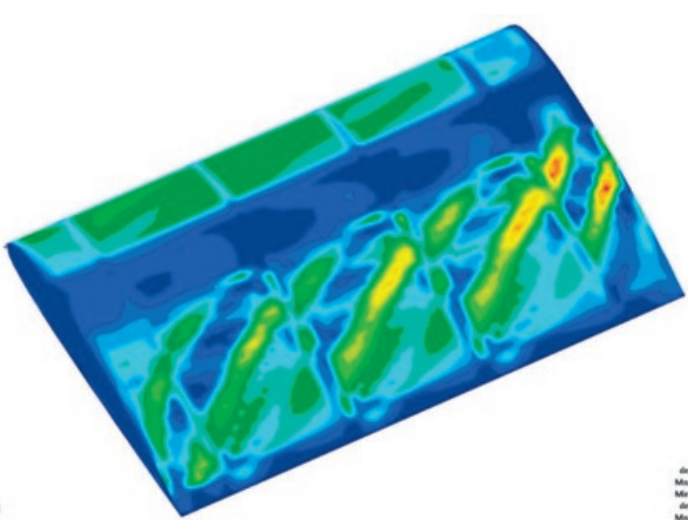

2010
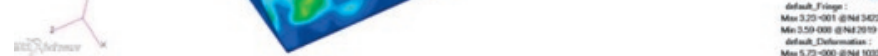

(a) model with ribs; (b) model with integral stiffening elements

stability occurred at very low load value as a result of occurrence of a field of tensions within the area of the observed segment.

On the other hand, comparison of solutions providing for ribs and integral stiffening elements have proven superiority of the latter which was also accompanied by a decrease of mass.

The increased rigidity of the whole structure can be explained by the fact that when ribs are employed, skin displacement in directions tangent to its surface at points where the skin is joined with the ribs becomes limited. This results in occurrence of different stress distributions in segments of the skin, more unfavourable from the point of view of overall effectiveness of the solution (Fig. 15).

\section{Summary and conclusions}

The combined experimental and numerical analysis of a number of design solutions for a typical fragment of thin-walled aircraft structure was focused on two fundamental goals. The first of the objectives 
included determination and comparison of operating properties of the examined structures with a maximum possible accuracy. The study has revealed that integral elements stiffening the skin applied in one of the considered model version, although based on a very simple technological solution, turned out to be more effective than the traditional variant providing for skin division by means of ribs. This allows to mark out a direction for further research aimed at determining an integral stiffening variant with properties most favourable in operating conditions specific for given structure. A criterion for selection of a target solution could be the largest critical load value or the smallest value of a deformation adopted as the representative one, with the structure mass changes taken into account at the same time.

The presented results of experimental studies and nonlinear numerical analyses, as well as conclusions derived from them, should be therefore assessed in the context of a broader framed research project aimed at determining properties of a number of stiffening elements for aircraft composite skins subjected to post-critical deformations under operating load conditions.

Another objective of the research project, constituting an indispensable complement to the experimental phase allowing to obtain knowledge of stress distribution patterns in the examined skins, consisted in development of appropriate and sufficiently effective FEM calculation models. Verified numerical models can constitute a very effective tool useful in search for another design solutions developed by means of using various combinations of stiffening elements. It should be however stressed that the last step must consist in performing an experiment with the use of a model corresponding to the selected variant. This follows from the absolute imperative to verify numerical models. Nevertheless, such methodology allows to eliminate the experimental component from intermediate design development stages identified as those leading to solutions that do not meet the selected criteria.

In the light of the above conclusions it can be found that the presented research methodology may prove finally to be an effective tool allowing to design skin stiffening solutions most favourable from the point of view of mass- and rigidity-related criteria. Meeting these criteria means that the desired operating properties of the examined structures have been achieved.

\title{
References
}

1. Arborcz J. Post-buckling behavior of structures. Numerical techniques for more complicated structures. Lecture Notes In Physics 1985; 288: 83-142.

2. Aborcz J., Hol J.M.A. Recent development in shell stability analysis, Report LR-633 Faculty of Aerospace Engineering. Delft: University of Technology, 1990.

3. Brzoska Z. Statyka i stateczność konstrukcji. Warszawa: PWN, 1965.

4. Crisfield M. A Non-linear finite element analysis of solid and structures. J. Wiley \& Sons, 1997.

5. Doyle J.F. Nonlinear analysis of thin-walled structures. Springer-Verlag, 2001, http://dx.doi.org/10.1007/978-1-4757-3546-8.

6. Dębski H., Kubiak T., Teter A. Experimental investigation of channel-section composite profiles' behavior with various sequences of plies subjected to static compression. Thin-Walled Structures, 2013; 71: 147-154, http://dx.doi.org/10.1016/j.tws.2013.07.008.

7. Dębski H. Experimental investigation of post-buckling behavior of composite column with top-hat cross-section. Eksploatacja i Niezawodnosc - Maintenance and Reliability, 2013; 16 (2): 1056-109.

8. Dobrzański P., Czarnocki P., Lorenz Z. Shell structures - theory and application. CRC Press, 2013, ISSN/ISBN 978-1-138-000-82-7, Vol. 3.

9. Felippa C. A., Crivelli L. A., Haugen B. A survey of the core-congruential formulation for nonlinear finite element. Archive of Computer Methods in Engineering, 1994, http://dx.doi.org/10.1007/BF02736179.

10. Jachimowicz J., Szymczyk E., Słowiński G., Derewońko A., Wronicz W. Modele globalne i lokalne MES w analizie struktur lotniczych na przykładzie fragmentu skrzydła samolotu M-28 Skytruck. Wyd. WAT, 2010, Biuletyn WAT Nr 1/2010.

11. Kopecki T., Mazurek P. Problems of numerical bifurcation reproducing in post-critical deformation states of aircraft structures. Journal of Theoretical and Applied Mechanics, 2013; 51(4): 969-977.

12. Kopecki T., Mazurek P. Numerical representation of post-critical deformations in the processes of determining stress distributions in closed multi-segment thin-walled aircraft load-bearing structures. Eksploatacja i Niezawodnosc - Maintenance and Reliability, 2014; 16(1):164-169.

13. Lynch C. A. Finite element study of the post buckling behavior of a typical aircraft fuselage panel. PhD Thesis, Queen's University Belfast, 2000.

14. Mielczarek G. Optimization of the structure of a multilayer cylindrical shell under stability loss conditions. Engineering Transaction, 1995, 43(4): 495-504.

15. Rakowski G., Kacprzyk Z. The finite elements method in mechanics of structures. Oficyna Wydawnicza Politechniki Warszawskiej, 1993.

16. Rudawska A., Dębski H. Experimental and numerical analysis of adhesively bonded aluminium alloy sheets joints, Eksploatacja i Niezawodnosc - Maintenance and Reliability, 2011; 49(1): 4-10.

17. Riks E. An incremental approach to the solution of snapping and buckling problems. International Journal of Solid and Structures, 1979; 15: 529-551, http://dx.doi.org/10.1016/0020-7683(79)90081-7.

18. Szymczyk E., Niezgoda T. Numeryczna analiza wyboczenia lokalnego użebrowanej powłoki cylindrycznej. Biuletyn Wojskowej Akademii Technicznej: budowa i eksploatacja maszyn, 2003; 1(605), 137-154.

19. Wiśniowski W. Sztywność i rozsztywnienie konstrukcji lotniczych. Prac Instytutu Lotnictwa No. 214, 2011, ISSN 0509-6669.

\author{
Tomasz KOPECKI \\ Przemysław MAZUREK \\ Tomasz LIS \\ Department of Mechanical Engineering and Aviation \\ Rzeszów University of Technology \\ al. Powstańców Warszawy 12, 35-959 Rzeszów, Poland \\ E-mails: tkopecki@prz.edu.pl, pmazurek@prz.edu.pl, list@prz.edu.pl
}

